\title{
ANALYZING LEARNING OBSTACLE WITH DIDACTICAL DESIGN RESEARCH ON THREE DIMENSIONAL DISTANCE MATERIAL
}

\author{
Dian Dharma ${ }^{1 *}$, Kamid ${ }^{2}$, Yantoro ${ }^{3}$ \\ ${ }^{1,2,3}$ Department of Mathematic Education, Postgraduate Program, Universitas Jambi, Indonesia \\ *Corresponding author: diandhrm10@gmail.com
}

\section{Article Info Article history: \\ Received: October 11, 2021 \\ Accepted: November 24, 2021 \\ Published: November 30, 2021}

Keywords:
Didactical design research
Learning obstace
Three dimensional distance
material

\begin{abstract}
The purpose of this study was to analyze the barriers to learning three-dimensional distance material using Didactical Design Research (DDR). The subjects of this study were two groups of class 12 . The instruments used in this study were pretest (initial test) and post test (final test) which consisted of a test of the respondent's ability, interview sheets, and observation notes. The data obtained were analyzed using three DDR steps: (1) didactic situation analysis by recontextualizing, repersonalizing, and developing didactic designs which include PDA (Pedagogical Didactic Anticipation); (2) metapedadidactic analysis by applying PDA; and (3) retrospective analysis linking didactic and metapedadidactic situations. The results showed that the identified learning obstacles can be anticipated by using PDA. The application of the didactic learning design shows that this design can be an alternative to thirddimensional distance learning in grade 12 because it can minimize student learning barriers that have been identified previously.
\end{abstract}

\section{ANALISIS LEARNING OBSTACLE MENGGUNAKAN DIDACTICAL DESIGN RESEARCH PADA MATERI JARAK DIMENSI TIGA}

\section{Kata Kunci:}

Didactical design research

Learning obstace

Materi jarak dimensi tiga

\section{ABSTRAK}

Penelitian ini menggunakan metode penelitian kualitatiF yang bertujuan untuk menganalisis learning obstacles materi jarak di dimensi tiga menggunakan Didactical Design Research (DDR) pada peserta didik. Subjek penelitian adalah dua kelompok peserta didik kelas XII. Instrumen yang digunakan adalah tes kemmapuan responden awal dan akhir, lembar wawancara, dan observasi. Data yang diperoleh dianalisis dengan tiga tahapan DDR yaitu, (1) analisis situaasi didaktis dengan melakukan rekontektualisasi, repersonalisasi, dan pengembangan desain didaktis termasuk ADP (Antisipasi Didaktis Pedagogis); (2) analisis metapedadidaktik dengan mengimplementasi ADP; dan (3) analisis retrospfektif yang mengaitkan situasi didaktis dengan metapedadidaktik. Hasil penelitian menunjukkan learning obstacle yang diidentifikasi dapat diantisipasi menggunakan ADP yang disiapkan. Implementasi desain pembelajaran didaktis menunjukkan bahwa desain ini dapat menjadi salah satu alternatif pembelajaran jarak pada dimensi tiga di kelas XII karena dapat meminimalisirlearning obstacles yang teridentifikasi sebelumnya kepada peserta didik. 


\section{INTRODUCTION}

The diverse abilities of students and the creativity of teachers in designing learning are things that must be considered to achieve the objectives of learning mathematics, because learning mathematics is a complex and continuous process and involves the interaction process of students, teachers and mathematics in it[1].In line with the 2013 curriculum which is dominated by a constructivist approach by paying attention to the response to the development of the learning process that wants the active role of students in engineering and initiating learning activities and constructing their own knowledge[2].Thus, the teachermust be able to develop certain tips so that the lesson presented can be well received by students.

In fact, during the learning process students naturally experience situations in the form of learning difficulties which will later cause a learning obstacle[3]. Learning obstacles also play an important role in learning because they force students to modify and adapt some aspects of their thinking to solve a given problem[4]. Three factors cause learning obstacles, namely, ontogenic obstacles related to mental readiness to learn, didactical obstacles related to teaching methods or strategies by teachers, and epistemological obstacles caused by limited knowledge in a context including understanding and applying mathematical contexts. A student is said to experience epistemological barriers when he cannot use his knowledge to solve a problem in a new context[5].Other forms of epistemological learning barriers are learning barriers related to difficulties in applying concepts, visualizing objects, determining the use of principles, and obstacles related to mathematical proof[6].In other words, epistemological barriers are part of the impact of ontogeny and didactic barriers.

Based on the results of observations to grade 12 students, it was found that there were learning barriers experienced in three-dimensional lessons. The obstacles found included difficulties in using facts including errors in completing pictures or answers and difficulties in operations including division and addition of fractions and roots.Meanwhile, the difficulty in using the concept is due to the lack of understanding of the students on the material provided. Barriers are difficulties experienced by students as a form of impact from the learning process which is still dominated by the teacher, so that it does not provide space to activate students' abilities which results in frequent misconceptions in students.Based on information obtained through interviews with several related sources, it is known that students memorize too often in mathematics lessons so that the concept of geometry becomes meaningless. Whereas in learning three-dimensional lessons it cannot only be done by transferring information, but requires a process of concept formation through a series of activities experienced by students directly.

Due to the many learning barriers experienced by students, it is necessary to prepare learning that is tailored to the characteristics of students to minimize the occurrence of these obstacles[7].One of the steps to overcome students' learning difficulties is through the process of planning, implementing, and evaluating the learning process, including the preparation of teaching materials that enable students to construct concepts and understandings[8].The right learning design and oriented to students' learning obstacles by paying attention to the mindset of students are expected to be able to overcome learning barriers so that the objectives of learning mathematics can be achieved[9].

Learning obstacle analysis can be done using the stages in Didactical Design Research (DDR). The stages of DDR are didactic situation analysis, metapedadidactic analysis by implementing PDA, and retrospective analysis which is an analysis that links the results of the hypothetical didactic situation analysis with the results of the metapedadidactic analysis.The results of retrospective analysis can be used to design 
learning tools that pay attention to student responses after implementing PDA through DDR. Responses that do not always match predictions make all prepared anticipations need to be modified again. This is important to do as a logical consequence of the view that essentially students have the authority to achieve abilities on their own capacity and the teacher is only there as a facilitator[10].

Pedagogical didactic analysis (PDA) is a synthesis of the results of the teacher's thinking based on various possibilities that are predicted to occur in learning by considering the identified learning obstacles that are expected to be useful for encouraging the learning process optimally and can attract students' interest in learning[11]. Through appropriate learning design and orientation to learning obstacles and facilitating mindsets with learning trajectories, we can overcome and anticipate the emergence of learning obstacles in learning mathematics[12]. Because the learning trajectory can signal the prerequisite knowledge that students have and the thinking processes and steps applied in the learning process[13].Learning trajectory is used as a tool to understand students' thinking so that teachers can create mathematics learning situations according to students' reasoning[14]. Through the identification of learning obstacles and learning trajectories, information is obtained to create a didactic design that not only takes into account the objectives, instructional tasks, and hypotheses about the learning process, but also the roles of teachers and students and the instructional resources used[15].

Referring to the problems presented, the researchers conducted research as an effort to improve the quality of learning through analysis of learning obstacles using didactical design research. The researcher analyzes the learning obstacles of the students to further create anticipation in the form of didactical design research, namely a hypothetical didactic design that can be applied in the classroom in order to build an understanding of mathematics learning so as to reduce students' difficulties. The preparation of learning designs oriented to the learning obstacles experienced and paying attention to the mindset of students, is expected to overcome the emergence of these learning barriers so that the objectives of learning mathematics can be achieved. This is because a learning design is needed to overcome the learning obstacles experienced by students[16].

The difference between this study and previous research is that this research also aims to optimize understanding of concepts and learning outcomes, especially on distance material in the third dimension in grade 12 of the Mathematics and Natural Sciences department. This is in line with the goal of achieving mathematics learning, namely, teachers who play a role in helping and guiding students to understand a knowledge. In addition, learning with didactical design research shows the teacher's understanding of the components of the didactic triangle including the study of material and concepts based on a scientific perspective and concerning the flow of thinking and learning objectives[17][18].Teachers are required to have the right knowledge in understanding and conditioning the diversity of students' lines of thinking, criticizing, and correcting instructions in books that are not appropriate, as well as developing various abilities of students[19]. Thus, this research can assist in creating a conducive and effective learning situation for students, so it is important for teachers to develop learning plans that are in accordance with the ability level of students..

\section{METHOD}

This type of research is qualitative by applying didactical design research. The research process by exploring difficulties as a form of student learning barriers in order to minimize these obstacles. The research process goes through three stages of teacher thinking in accordance with DDR. The first stage is a didactic situation analysis to 
determine what, why, when, where, and how an action will be taken, including identification of the learning obstacles of students and repersonalization activities to examine and analyze the material to be studied for further preparation of a learning design called pedagogical didactic anticipation. Pedagogical Didactic Anticipation is an anticipatory relationship between the teacher and the lesson during the learning process, which includes learning styles and methods, and the teacher's ability to design teaching materials. The second stage is metapedadidactic analysis as the implementation stage of the PDA design that has been made. The third stage is a retrospective analysis to review the parts of the design that are working or not working well for revision and to find out whether the identified learning barriers still exist or not. Furthermore, the researchers compiled a revision of the learning design, an empirical didactic design that did not rule out the possibility to continue to be refined through the three stages of DDR by subsequent researchers. Figure 1 illustrates the outline of the research flow.

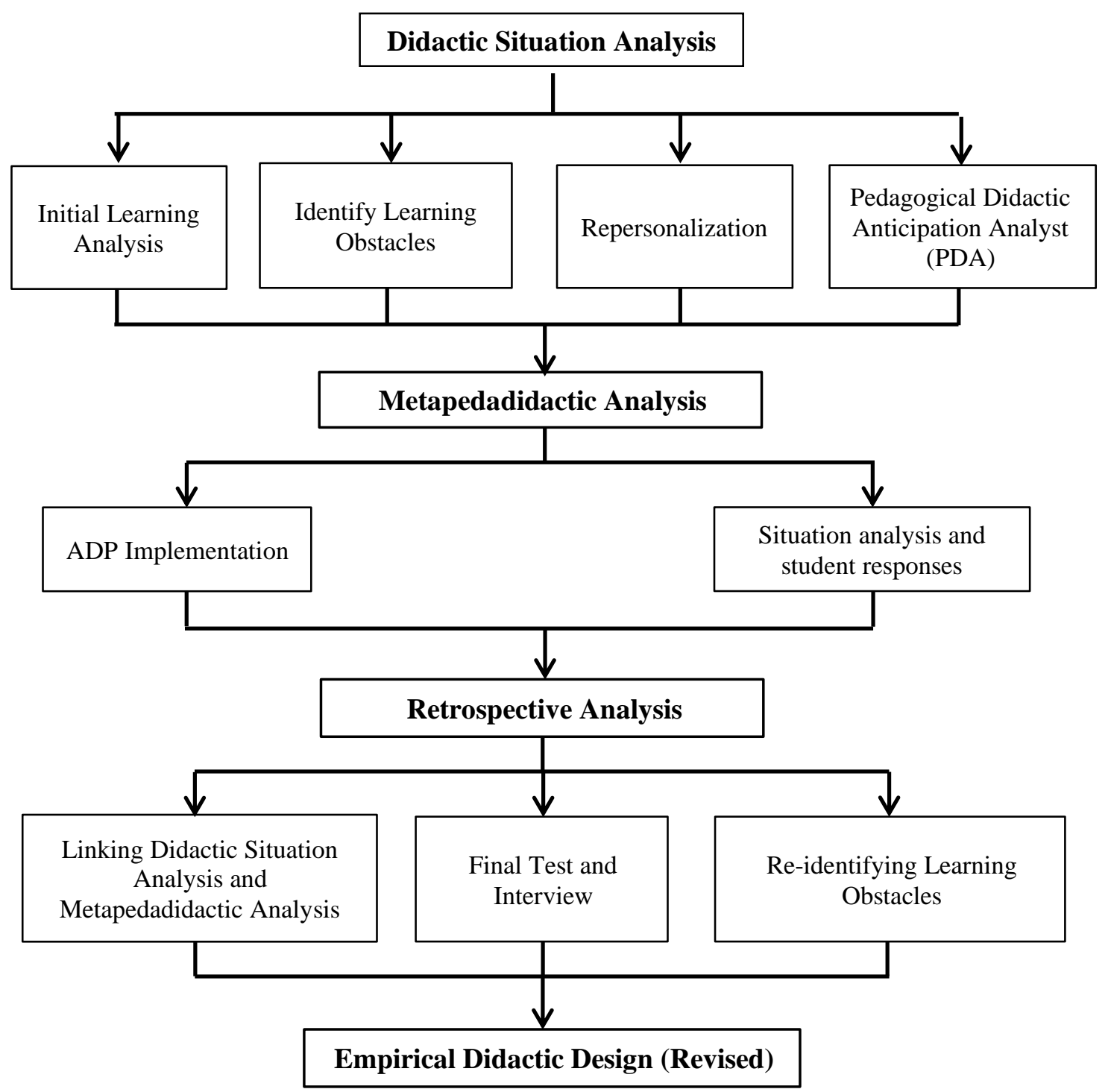

Figure 1. The Outline of the Research Flow

The study involved students in grade 12 who had studied distance in the third dimension who were in the didactic situation analysis stage and grade 12 students who would study distance in the third dimension for metapedadidactic and retrospective 
analysis. The main instrument used is a researcher who acts to design, collect data, analyze data, interpret data, and record research results. While the supporting instruments used are the ability test of the initial and final respondents, the results of interviews, and observations. The design used in the research is in the form of a PDA which can later be analyzed and revised so that an empirical didactic design is obtained which does not rule out the possibility to continue to be refined through the DDR stage.

\section{RESULTS AND DISCUSSION}

The results of the research presented include changes in the learning obstacle of students through learning with the initial didactic design until a revised didactic design is obtained. The initial didactic design was prepared to minimize the learning obstacles that have been revealed through the initial instrument for class 12 students majoring in Mathematics and Natural Sciences for the 2020/2021 academic year. While the revised design is the result of implementation and the final instrument. This learning design is one of the stages so that the learning objectives can be achieved.

\subsection{Didactic Situation Analysis}

In order to support the results of the didactic situation analysis at the recontextualization stage, the researcher conducted an analysis of the previous learning by interviewing the 12th grade math teacher and conducting a pre-test (initial test). This is done to obtain a hypothetical didactic design that fits the student's learning trajectory in order to overcome learning obstacles from the results of the diagnostic test[20].

The results of observations and tests succeeded in revealing several difficulties which were included in the epistemological barriers experienced by one of the subjects, namely difficulties in understanding the concept of the position of points, lines, and planes in the shape of a space, difficulties in visualizing images including projecting points on lines and planes, difficulties in performing the calculation procedure using the triangle approach and the Pythagorean theorem, and the difficulty of determining the type of triangle and the position of the perpendicular line. From the results of the interview, it is known that difficulties and errors occur because the subject only understands certain contexts in the mathematical problems that are exemplified, so that when students are given different forms of problems, students experience difficulties. This includes epistemological barriers because the information received by students to become knowledge is only partially understood[21].The following is an example of subject's initial test answers.

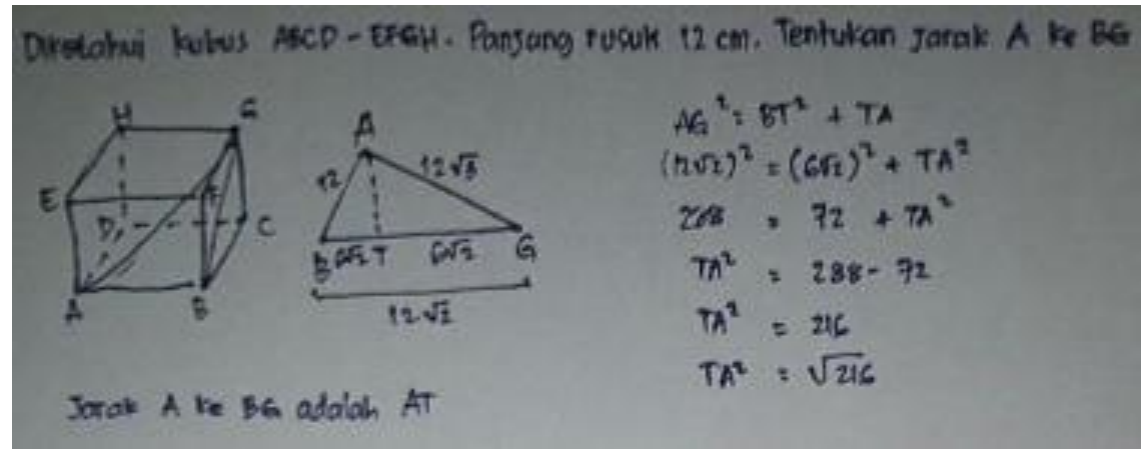

Figure 2. Subject's Initial Test Answers

Furthermore, the researcher conducted repersonalization by analyzing the material with three-dimensional distance by examining the context and concepts. Researchers conducted an analysis of the distance in the three dimensions of several textbooks used. 
The analysis of these books aims to obtain an overview of the flow of material given to students as one of the studies on didactical obstacles. Due to the condition of pedagogical incompetence and the teacher's lack of knowledge regarding the material, it can be the main cause of students' difficulties in understanding concepts[22][23].In addition, when a textbook has not facilitated the right flow and instructions, then the teacher and students are fixated on the book, the learning carried out can trigger the emergence of learning obstacles[24]. Repersonalization is also carried out because previous teachers tend to involve the book completely without caring about the truth or accuracy of the instructions, plot, or material delivered[25]. By considering the effectiveness and efficiency of learning activities in the classroom, the researchers formulated a concept map of learning during the study as follows.

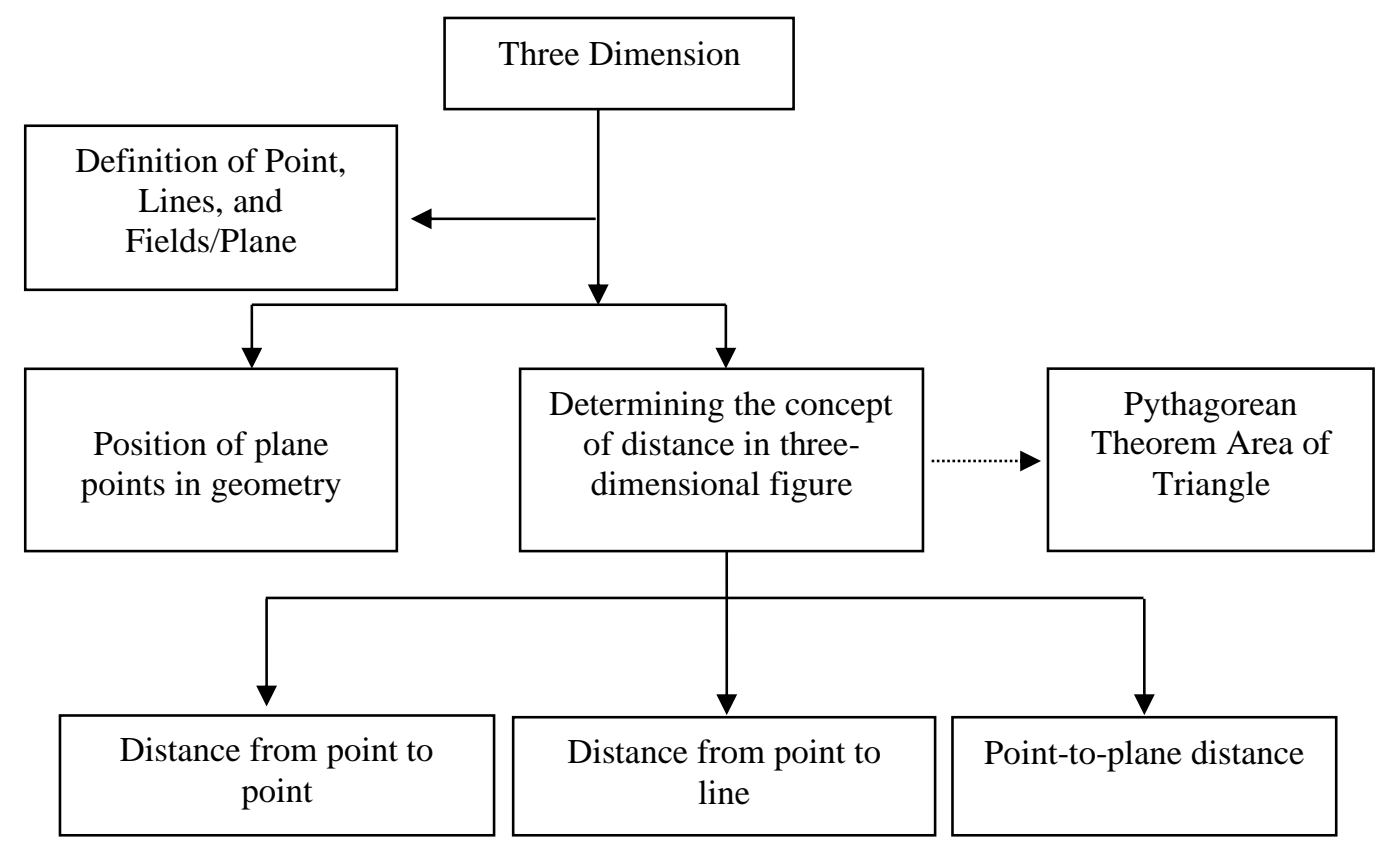

Figure 3. Mind Mapping Distance in Three Dimensions

Researchers use worksheets as part of teaching materials which not only contain questions but also activity steps that can be applied by students. Thus, students are more able to determine the distance in the shape of the space than just giving questions without explanations of the work like the previous worksheet. After doing recontextualization and repersonalization, the researcher developed a learning design that contained activities, responses including obstacles that might be experienced, and their anticipation.

Anticipation of student responses is called Pedagogical Didactic Anticipation (PDA). PDA is the result of learning obstacle analysis and material repersonalization that has the potential to produce innovative didactic designs that can be formulated as a series of steps to produce new didactic designs[10]. This anticipation is used to reduce learning obstacles related to distance learning in three dimensions.

The hypothetical didactic design was made into four learning designs which were detailed based on the epistemological barriers found. The learning design for each meeting has a PDA with different activities, goals and predictions of student responses according to the obstacles experienced. Table 1 defines the initial hypothetical didactic design used. 
Table 1. Examples of Initial Hypothetical Didactic Designs

\begin{tabular}{|c|c|c|c|c|}
\hline $\begin{array}{c}\text { Epistemological } \\
\text { Obstacles }\end{array}$ & $\begin{array}{l}\text { Didactic } \\
\text { Situation }\end{array}$ & Activities & Response Prediction & $\begin{array}{c}\text { Pedagogical } \\
\text { Didactic } \\
\text { Anticipation } \\
\end{array}$ \\
\hline \multirow[t]{2}{*}{$\begin{array}{l}\text { Students find } \\
\text { it difficult to } \\
\text { understand the } \\
\text { concept of } \\
\text { point-to-plane } \\
\text { distance }\end{array}$} & \multirow[t]{2}{*}{$\begin{array}{l}\text { The } \\
\text { teacher } \\
\text { displays an } \\
\text { illustration } \\
\text { in the form } \\
\text { of a picture } \\
\text { of several } \\
\text { pillars to } \\
\text { support the } \\
\text { roof of a } \\
\text { building. }\end{array}$} & $\begin{array}{l}\text { Students are asked } \\
\text { to look at the } \\
\text { picture of the } \\
\text { supporting wood } \\
\text { and the roof to } \\
\text { determine the } \\
\text { conditions or } \\
\text { requirements so that } \\
\text { the length of the } \\
\text { support wood used } \\
\text { is as minimal as } \\
\text { possible }\end{array}$ & $\begin{array}{l}\text { Expected response: } \\
\text { Students pay attention to } \\
\text { the illustrations presented } \\
\text { by the teacher and can } \\
\text { express their opinions } \\
\text { regarding the requirements } \\
\text { so that the length of the } \\
\text { supporting wood used is as } \\
\text { minimal as possible } \\
\text { Possible difficulties: } \\
\text { Students have difficulty in } \\
\text { expressing opinions about } \\
\text { the requirements so that } \\
\text { the length of the support } \\
\text { wood used is as minimal } \\
\text { as possible. }\end{array}$ & $\begin{array}{l}\text { The teacher guides } \\
\text { students to identify } \\
\text { the distance of a } \\
\text { point on one side of } \\
\text { the building and a } \\
\text { point on the roof } \\
\text { plane as shown in } \\
\text { the picture by } \\
\text { clarifying the } \\
\text { illustration }\end{array}$ \\
\hline & & $\begin{array}{l}\text { Students are asked } \\
\text { to rewrite the } \\
\text { definition of the } \\
\text { distance from a } \\
\text { point to a plane } \\
\text { based on the } \\
\text { illustration } \\
\text { provided. }\end{array}$ & $\begin{array}{l}\text { Expected response: } \\
\text { Students can rewrite the } \\
\text { definition of the distance } \\
\text { from a point to a plane } \\
\text { based on the illustrations } \\
\text { and previous activities. } \\
\text { Possible difficulties: } \\
\text { Students find it difficult to } \\
\text { redefine the distance of the } \\
\text { point to the plane. }\end{array}$ & $\begin{array}{l}\text { The teacher gives a } \\
\text { stimulus to the } \\
\text { students by linking } \\
\text { the illustration of } \\
\text { the pillars and roof } \\
\text { with the illustration } \\
\text { of point } P \text { and plane } \\
\alpha \text { which is } \\
\text { presented and helps } \\
\text { to explain based on } \\
\text { the picture. }\end{array}$ \\
\hline
\end{tabular}

Learning design begins by inserting images that students are likely to find in everyday life. Analysis of the characteristics contained in the spatial structure is carried out through available media. Furthermore, students are asked to re-describe the illustration according to the learning concept carried out. This is in accordance with Ausubel's theory of meaningful learning which is defined as the process of linking relevant information and concepts through the stages of knowing, understanding, applying, and possessing it for further use.

The next activity is to identify the relationship of each element related to the distance in the third dimension with various given spatial shapes. Researchers insert online quiz activities with a set time for each question and each question is given a picture of various shapes that can be identified by students. This is done as a form of anticipation for the difficulty of students determining the position of points, lines, and planes in a spatial structure based on the Van Hiele theory of Rigor level.

In the next stage, the researcher provides an example of a spatial shape to determine the line segment that represents the desired distance. The researcher introduced the projection procedure to students as an important step in three-dimensional teaching material. The activity was continued by calculating the distance from one element to another in three dimensions using the Pythagorean theorem and the area of a triangle with the concept of similarity. In the final activity, the researcher gave evaluation questions that 
had to be done independently by each student with the aim of seeing the extent to which they were able to understand the lesson given at each meeting.

The designed didactic situation is implemented by the researcher so as to provide opportunities for students to use their knowledge and absorb new information through different patterns. In the didactic triangle, the teacher plays a role in creating a didactic situation in the learning process for students. In a didactic environment that is prepared and applied by the teacher, it is possible to change the knowledge of students and provide new information to them[26]. The didactic situation that is designed has sufficient flexibility to adjust to the ability of the students' thinking level[27]. Didactic and pedagogical situations are very complex, so teachers must have the ability to look at them comprehensively, be able to identify and analyze important things that happen, and take appropriate actions so that learning becomes optimal[28].Thus, for the next stage based on the didactic situation analysis, followed by the second phase, namely implementing the learning design with ADP which is designed to be analyzed again at the metapedadidactic analysis stage.

\subsection{Metapedadidactic Analysis}

Through the implementation of the initial hypothetical didactic design, several things were known, including student responses according to predictions made previously, response predictions that did not appear, and new responses that became the latest epistemological barriers. Table 2 shows the results of metapedadidactic observations of the designs that have been applied to students.

Table 2. Metapedadidactic Observation Sheet

\begin{tabular}{|c|c|c|c|c|c|}
\hline $\begin{array}{l}\text { Response } \\
\text { Prediction }\end{array}$ & Information & Anticipation & Information & $\begin{array}{c}\text { New } \\
\text { Epistemological } \\
\text { Obstacles } \\
\end{array}$ & Solution \\
\hline $\begin{array}{l}\text { Expected } \\
\text { response: } \\
\text { Students can re- } \\
\text { express the } \\
\text { condition for } \\
\text { determining the } \\
\text { distance from a } \\
\text { point to a line by } \\
\text { projecting a point } \\
\text { to a line that has } \\
\text { an angle of } 90^{\circ} \\
\text { (perpendicular) to } \\
\text { the line and has } \\
\text { the shortest line } \\
\text { segment length. } \\
\text { Students find it } \\
\text { difficult to re- } \\
\text { express the } \\
\text { conditions for } \\
\text { determining the } \\
\text { distance from a } \\
\text { point to a line. }\end{array}$ & $X$ & $\begin{array}{l}\text { The teacher provides a } \\
\text { stimulus to make } \\
\text { students think by } \\
\text { presenting an } \\
\text { illustration of the } \\
\text { distance from point A } \\
\text { to line } \mathrm{g} \text { which is } \\
\text { represented by the line } \\
\text { segment AP. }\end{array}$ & $\begin{array}{c}\text { Less } \\
\text { effective }\end{array}$ & $\begin{array}{l}\text { With different } \\
\text { cases, } \\
\text { students again } \\
\text { find it } \\
\text { difficult to } \\
\text { determine the } \\
\text { conditions for } \\
\text { the distance } \\
\text { from the point } \\
\text { to the line. }\end{array}$ & $\begin{array}{l}\text { The teacher } \\
\text { gives examples } \\
\text { of different } \\
\text { cases to develop } \\
\text { and strengthen } \\
\text { the ability of } \\
\text { students to } \\
\text { restate the } \\
\text { conditions for } \\
\text { the distance } \\
\text { from a point to } \\
\text { a line. }\end{array}$ \\
\hline
\end{tabular}

The implementation of the first design regarding the position of points, lines, and planes in the shape of the space to the proof of perpendicular lines in the plane. In this design, there are activities that ask students to visualize the illustrations by adjusting them and then expressing their opinions about their respective positions. However, there were 
several activities that gave rise to a response in the form of difficulties so that the planned anticipation was implemented. But it was also found that there was a new response that was not found in the design that was made so that another solution was needed that was noted for revision.

The second didactic design deals with the distance from point to point in geometry. Similar to the previous design, there is a student response that is in accordance with the design so that the planned anticipation can be applied. Students have difficulty not understanding the use of the previous side diagonal information and existing triangles to calculate the distance from point B to the midpoint of EG. However, the anticipation used is less effective, besides that there are new difficulties that arise so that another more effective anticipation is needed.

The third didactic design discusses the distance of the point to the line in geometry. One of the difficulties experienced by students according to predictions is in determining the representative distance between the penalty point and the goal line according to the illustration given. The researcher applies the prepared anticipation and the results given afterwards show that the anticipation is effective to use. In addition, there are also new difficulties that were not predicted by the researcher and used as a reference for making new solutions in the revision section.

The fourth didactic design deals with point-to-plane distances in geometry. During the implementation of the fourth design, not much response was found outside the designed design. In addition, students do not experience as many difficulties as previously predicted. This is because in the second to fourth didactic designs, the objectives of the activities carried out have similarities, namely starting from describing the distance of the point to its elements, identifying the distance of the point to its elements, calculating the distance of the point to its elements, and practicing as a summary to see the ability of students. overall. For four times using the indirect hypothetical didactic design, students have experienced the same situation and related material to be repeated.

After learning with the initial hypothetical didactic design, it turned out that there were very good developmental changes by the students. Through the implementation of the initial hypothetical didactic design, it turns out that the results are quite capable of overcoming the obstacles that arise in learning, developing student competencies and being able to change their behavior in solving geometric problems[27]. However, although there are still some learning barriers that still arise and new difficulties are not uncommon, it can be seen from the worksheets and observations during learning which show results that are very close to the learning objectives. Properly planned learning through the process of repersonalization and recontextualization of the material to be taught, as well as properly designing the didactic design will greatly affect success in learning[29]. Thus, it can be said that the teacher must be one step ahead, including in predicting and ensuring the response of students in the learning process in order to overcome other possible difficulties that are shown by students during learning.

\subsection{Retrospective Analysis}

At this stage, a final test is conducted to determine the effectiveness of the didactic design that has been applied. The instrument used is the same as the questions used in the initial test. The test results show that there has been a very good change from the learning obstacles that have been identified previously.

Retrospective analysis is the stage to link the results of the didactic situation analysis with the metapedadidactic analysis to produce an empirical didactic design. In order to find the impact of implementing the initial learning design, the researcher conducted a final test 
on students with the same instrument as the one used in the initial test. The results of the final test showed that the average value of the students had a significant difference compared to the results of the initial test that was followed by the previous 12th grade students. The maximum value obtained is a score of 43 or it is said to be complete. figure 4 is an example of student's final exam answers.

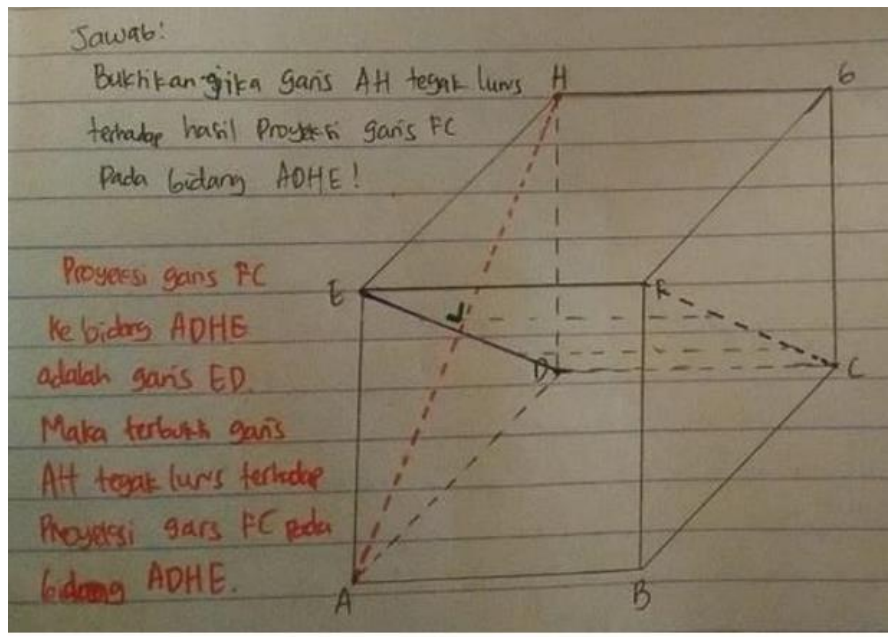

Figure 4. Student's Final Test Answers (i)

Figure 4 is an example of the perfect answer expected and almost $50 \%$ of students understand and write almost similar answers. Students are able to provide visualizations as well as reasons that are in accordance with the concepts learned about proving perpendicular to lines in geometric shapes. However, there are still some students who experience obstacles in working on this question.

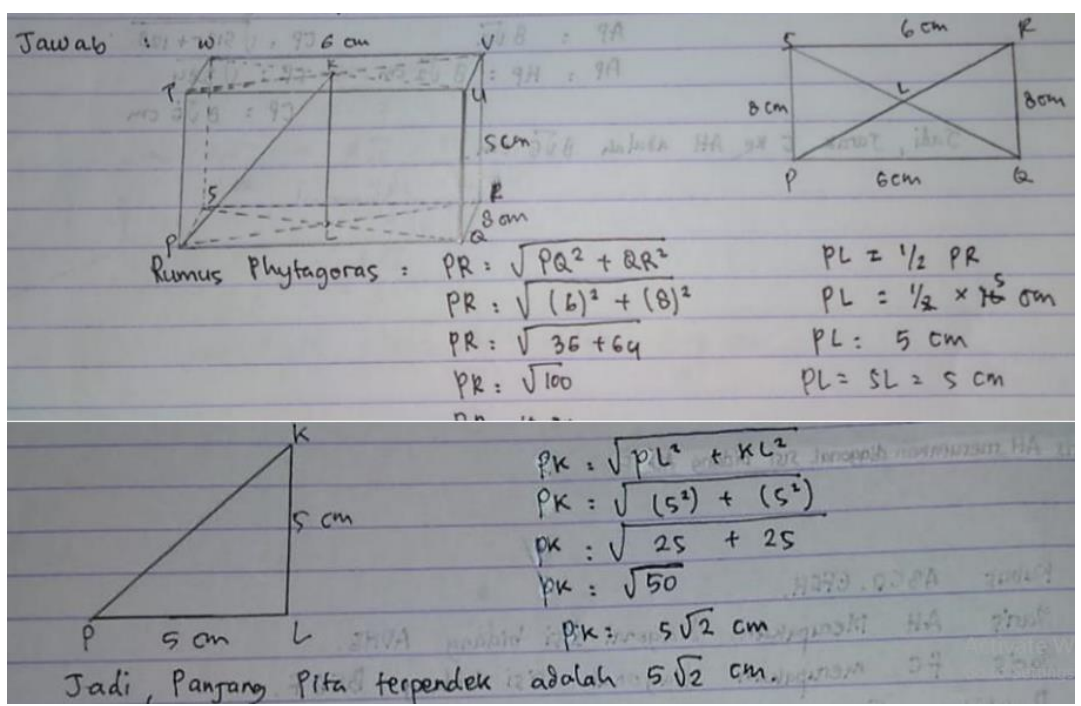

Figure 5. Student's Final Test Answers (ii)

Based on Figure 5, it appears that students have abstracted the questions into the form of pictures correctly. In addition, the line segment used as the result of the projection is appropriate so that the calculation obtained is correct. However, only 6 out of 20 students gave answers like Figure 5, while the rest gave answers that varied in error. In other words, related to contextual questions, there are still many students who experience difficulties so that they are hampered in working on the questions given. 


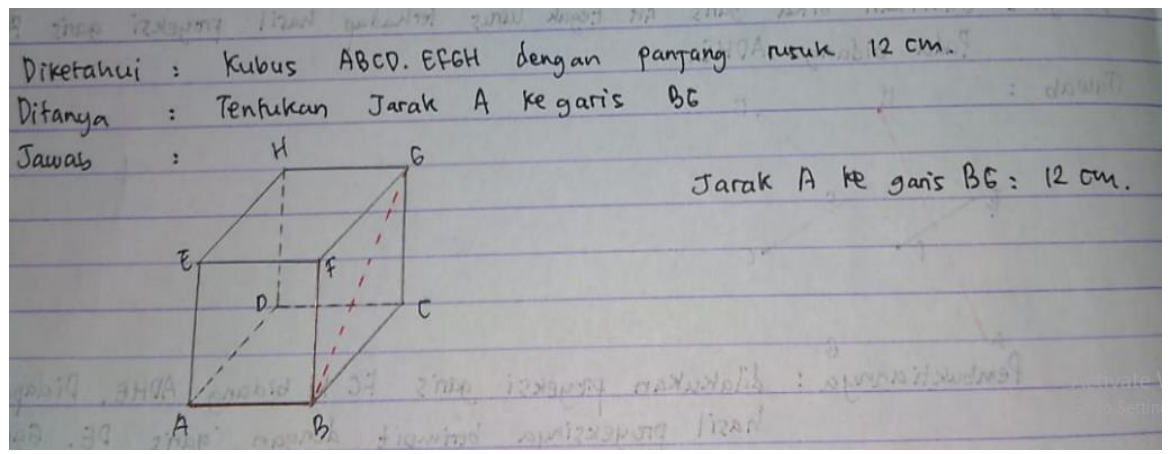

Figure 6. Student's Final Test Answers (iii)

Figure 6 is an example of a simple question in which many errors were found in the students' answers in the initial test. Meanwhile, in the final test, all students were able to do this question perfectly. All students are able to answer and when randomly selected to explain the reasons for the answers written, students can give reasons for using the right concept.

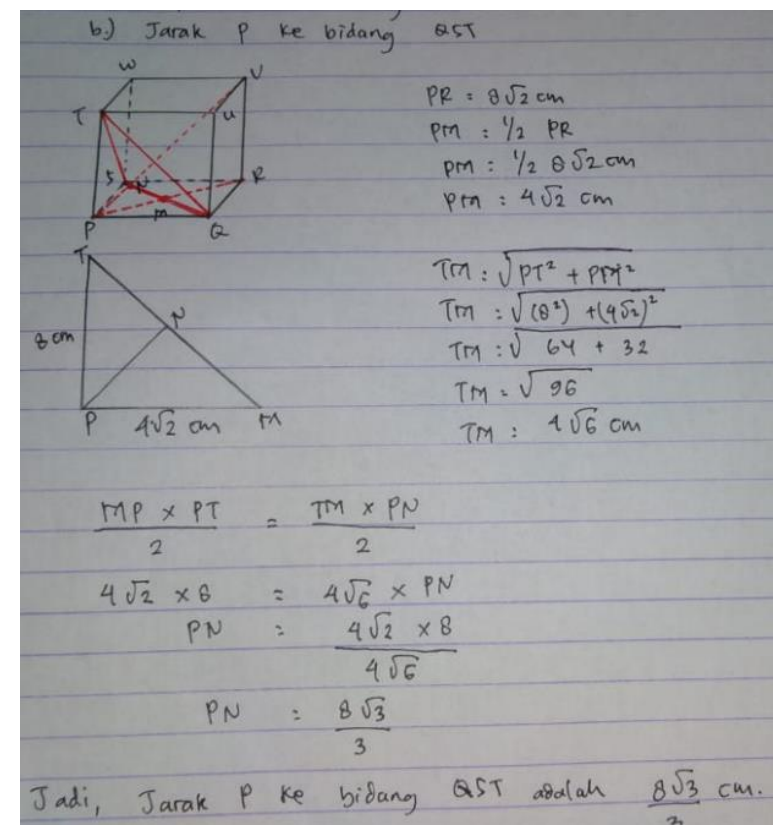

Figure 7. Student's Final Test Answers (iv)

Figure 7 is an example of the answers of students who have mastered the concept correctly starting from abstracting into image form to calculating by utilizing side diagonal information. But in reality, only a few students gave the answers as shown in Figure 7 perfectly, only about 7 people. While others still make a little mistake. One of the mistakes made by students is shown in Figure 8.

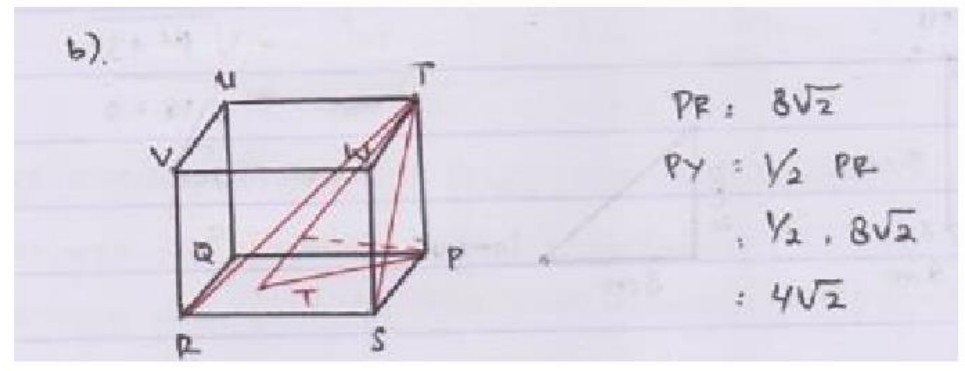

Figure 8. Student's Final Test Answers (v) 
Figure 8 is the answer to one of the subjects with the same question as Figure 7. In Figure 8 it appears that the answers given by a student to the abstraction of the image are wrong. Student has not described the distance between a point and a plane accurately and have an impact on calculation errors. Student said that he did not understand the concept of the distance from a point to a plane when it was applied to a problem and they were asked to describe it. Student is still confused in determining the projection of a point on a plane in a shape so that the line segment that should be used as a distance is not even found. However, some of them have understood the concepts of distance and perpendicular that should be used in the material being studied.

Furthermore, based on a retrospective analysis, the anticipation can be rearranged in the form of a revised learning design. Some examples of revised didactic designs taking into account the results of implementation and final tests are as follows:

1. New difficulties arise in discussing the position of points, lines, and planes where students cannot distinguish between lines and line segments. This is the basis for researchers to add anticipation in the form of presenting illustrations of differences in lines and line segments.

2. 2. Students have not mastered the proof of perpendicular lines in the field because they still have difficulty understanding the definition of perpendicularity itself. Anticipation made by the teacher by describing and providing illustrations that provide more instructions for students to follow.

3. Some students find it difficult to find a triangle that can be used as an approach in determining the distance to be calculated. Anticipation is done by providing a picture as a guide followed by helpful steps on the worksheet.

4. Students have difficulty finding line segments that represent distances as a result of point-to-line projections on the given pyramid space. The researcher made a revision by adding instructions in the form of a pyramid image, one of which had been directed to a projection point and a line segment as a distance, while the next question remained the same and students determined themselves based on the example.

In previous studies, it was found that there was a decrease in learning obstacles after the implementation of the didactic design that appeared, namely 4 out of 15 learning obstacles in trigonometry material[30]. In addition, in other studies, it was found that the created didactic situation encourages the learning process optimally and can attract students' interest in learning[11]. Thus, this strengthens the results of research conducted by researchers, namely based on the results of the final respondent's ability test, it is known that most of the learning obstacles identified in the initial test were resolved after the didactic design and anticipation made by the researchers were applied.

Furthermore, the revision of the learning design was carried out by researchers based on the results of a retrospective analysis of the implementation results which led to several changes related to the situation contained in each learning design, resulting in an empirical didactic design. In addition, the structure of commands and questions, the elimination of pictures, and the addition of certain activities can make it easier and construct the understanding of students[20]. Thus, improvement of direction and guidance is needed, especially in the process of abstracting real situations into a learning concept from time to time.

\section{CONCLUSION}

Based on the results of the study, it was found that the identified learning difficulties could be minimized through the implementation of the didactic design in the form of pedagogical didactic anticipation. The hypothetical didactic design was prepared based on 
the results of the learning obstacle analysis and hypothetical learning trajectory to form a pedagogical didactic anticipation (PDA). The hypothetical didactic design contains situations related to the concept of distance of points, lines, and planes which are partitioned into four learning designs. Minimized learning obstacles include students' difficulties in proving the position of points, lines, and fields, determining the results of point projections to lines, making a field containing line segments as the distance asked, and calculating the distance from point to point, point to line, and point to plane using the Pythagorean theorem and/or the area of a triangle with the principle of similarity. However, some responses were also found outside the design so that a revision of the anticipation was needed to make an empirical didactic design.

\section{REFERENCES}

[1] D. Suryadi, "Menciptakan Proses Belajar Aktif: Kajian dari Sudut Pandang Teori Belajar dan Teori Didaktik - Modul Seminar Nasional Pendidikan Matematika UNP Padang." UPI, Bandung, 2010.

[2] J. Khatimah, Husnul; Kamid; Marzal, "The Development of Student Worksheets Based on APOS Theory (Action, Processe, Object, Scheme) to Elevate the Effectivity in Learning Mathematics," J. Pendidik. Mat. dan Ilmu Pengetah. Alam, vol. 4, no. 2, 2015.

[3] G. Brousseau and V. Warfield, "Didactic situations in mathematics education," Encycl. Math. Educ., 2020, [Online]. Available: https://link.springer.com/content/pdf/10.1007/978-3-030-15789-0_47.pdf.

[4] M. L. Bishop, J. P., Lamb, L. L., Philipp, R. A., Whitacre, I., Schappelle, B. P., \& Lewis, "Obstacles and Affordances for Integer Reasoning: An Analysis of Children's Thinking and the History of Mathematics," J. Res. Math. Educ., vol. 45, no. 1, pp. 19-61, 2014, doi: 128.248.155.225.

[5] N. Hercovics, "The Description and Analysis of Mathematical Processes." Center for Mathematics, Science, and Computer Education Rutgers, New Jersey, 1989.

[6] M. Noto, "Analysis of learning obstacles on transformation geometry," Journal of Physics: Conference Series, vol. 1157, no. 4. 2019, doi: 10.1088/17426596/1157/4/042100.

[7] A. Cesaria, "Learning obstacle in geometry," J. Eng. Sci. Technol., vol. 14, no. 3, pp. 1271-1280, 2019, [Online]. Available: https://www.scopus.com/inward/record.uri?partnerID=HzOxMe3b\&scp=8507201 8545\&origin=inward.

[8] T. Adolphus, "Problem of Teaching and Learning of Geometry in Secondary School in Rivers State, Nigeria," Int. J. Emerg. Sci, vol. 1, no. 2, pp. 143-152, 2011.

[9] E. Sumiaty, "Didactical design work sheet of complex variable function based on epistemology, didactical, and learning trajectory to enhance student's ability for representation and communication," Journal of Physics: Conference Series, vol. 1280, no. 4. 2019, doi: 10.1088/1742-6596/1280/4/042033.

[10] D. Suryadi, "Didactical Design Research (DDR) Dalam Pengembangan Pembelajaran Matematika1 - Modul Seminar Nasional FPMIPA UPI." UPI, Bandung, 2016.

[11] R. A. Fitriani, Nelly., Gida Kadarisma, "Pengembangan Desain Didaktis Untuk Mengatasi Learning Obstacle Pada Materi Dimensi Tiga," J. Progr. Stud. Pendidik. Mat., vol. 9, no. 2, pp. 231-241, 2020, doi: https://doi.org/10.24127/ajpm.v9i2.2686.

[12] M. Artigue, "Didactic engineering in mathematics education," Encycl. Math. Educ., 
2020, [Online]. Available: https://link.springer.com/content/pdf/10.1007/978-3030-15789-0_44.pdf.

[13] M. . Simon, "Reconstructing Mathematics Pedagogy from a Contructivist Perspective," J. Res. Math. Educ., vol. 26, no. 2, pp. 114-145, 1995.

[14] J. C. Wilson, P. Holt., Gemma F.M., "Learning Trajectories in Teacher Education: Supporting Teachers' Understandings of Students' Mathematical Thinking," $J$. Math. Behav., vol. 32, no. 2, pp. 103-121, 2013.

[15] M. R. W. Godino, Juan, D., Rivas H., "Analysis of Didactical Trajectories in Teaching and Learning Mathematics: Overcoming Extreme Objectivist and Constructivist Positions," Int. Electron. J. Math. Educ., vol. 14, no. 1, pp. 147-161, 2019.

[16] Sumiatik, "Desain Didaktis Sistem Persamaan Linear Tiga Variabel Di Kelas X MA Al-Mustaqim," Pontianak: Universitas Tanjungpura, 2019.

[17] D. Mulyana, E., Turmudi \& Juandi, "Model pengembangan Desain Didaktis Subject Specific PedagogyBidang Matematika Melalui Program Pendidikan Profesi Guru," J. Pengajaran MIPA, vol. 19, no. 2, pp. 141-149.

[18] S. Bikner-Ahsbahs, A. \& Prediger, Networking of Theories as a Research Practice in Mathematics Education. Springer, 2014.

[19] A. V Erten, S., Şen, C. \& Yüzüak, "A Critical Analysis to 5thGrade Elementary Science EducationTextbook.," Int. J. Humanit. Soc. Sci. Educ., vol. 2, no. 1, pp. 16, 2015.

[20] M. A. H. T. D. J. A. Jatmiko, "Desain Didaktis Materi Kaidah Pencacahan Untuk Siswa SMA Kelas XI," J. Res. Math. Educ., vol. 4, no. 35-54, 2021.

[21] A. A. Haqq, "Pengembangan Desain Didaktis Geometri Berbantuan Perangkat Lunak Cabri 3D pada Pembelajaran Matematika SMA," Theorems (The Orig. Res. Math., vol. 5, no. 1, 2020.

[22] R. E. Orrill, C.H.\& Brown, "NumberLines in Profesional Development: Exploring Teachers' Understandings of Proportional Relationships," J. Math. Teach. Educ., no. 15 , pp. 381-403, 2012.

[23] K. Ekawati, R., Lin, F. \& Yang, "Developing an Instrument for Measuring Teachers' Mathematics Content Knowledge on Ratio and Proportion: A Case of Indonesian Primary Teachers," Int. J. Sci. Math. Educ., vol. 13, no. 1, pp. 1-24, 2014.

[24] A. Wijaya, "The Relationships Between Indonesian Fourth Graders' Difficulties in Fractions and The Opportunity to Learn Fractions: A Snapshot of TIMSS Results," Int. J. Instr., vol. 10, no. 4, pp. 221-236, 2017.

[25] K. Kumar,R. S. \& Subramaniam, "From 'Following' to 'Going Beyond' The Textbook: In-Service Indian mathematics Teachers' Professional Development for Teaching Integers," Aust. J. Teach. Educ., vol. 40, no. 12, pp. 86-103, 2015.

[26] S. Arslan, Selahattin; Baran, Demet; Oku, us, "Brousseau's Theory of Didactical Situations in Mathematics and An Application of Adidactical Situations," Necatibey Fac. Educ. Electron. J. Sci. Math. Educ., vol. 5, no. 1, pp. 204-224, 2011.

[27] D. Setiadi, "Didactical Design Enrichment of Angle in Geometry," Journal of Physics: Conference Series, vol. 895, no. 1. 2017, doi: 10.1088/17426596/895/1/012060.

[28] S. Sulistiawati; Suryadi, Didi; Fatimah, "Desain Didaktis Penalaran Matematis untuk Mengatasi Kesulitan Belajar Siswa SMP pada Luas dan Volume Limas," J. Mat. Kreat., vol. 6, no. 2, pp. 135-146, 2015.

[29] A. Pratamawati, "Desain Didaktis untuk Mengatasi Learning Obstacle Siswa 
Sekolah Menengah Atas pada Materi Fungsi Invers," J. Pendidik. Mat., vol. 3, no. 1, pp. 15-28, 2020.

[30] A. A. . Sakinah, E., Darwan., "Desain Didaktis Materi Trigonometri dalam Upaya Meminimalisir Hambatan Belajar Siswa," Suska J. Math. Educ., vol. 5, no. 121130, 2019. 